\title{
DIPLOMACY AND THE KARCZMAITABERNA: THE ROLE OF CRACOVIAN PUBLIC HOUSES IN THE DIPLOMATIC PRACTICE OF THE JAGIELLONIANS (1430-1540)
}

\author{
Peter Dobek (D) http://orcid.org/0000-0001-9733-9884 \\ Grand Valley State University
}

\begin{abstract}
Public houses - inns, taverns, and alehouses - during the Jagiellonian Dynasty (1385-1572) in Cracow functioned as important establishments in the diplomatic services of kings, city officials, and the nobility. Not only did these locales offer drink, food, and accommodations to emissaries for their travels and work, but they provided much more. For the diplomats, the inns, taverns, and alehouses were sites to learn the latest news, gossip, and public opinion. They provided a place to fraternize and they were also trusted locations for sensitive diplomatic negotiations. Public houses likewise served as "post offices" where envoys could receive their letters. Although scholars have studied these establishments, the diplomacy, and urban history throughout Europe in various epochs, they have neglected to analyze the role of the Cracovian public houses in diplomatic services in the Jagiellonian era. This article provides a comprehensive examination of sources, including royal and municipal accounting and personal correspondence, to reveal the role of public houses in the diplomatic practices of the Jagiellonian dynasty.
\end{abstract}

Keywords: public houses, diplomatic services, Cracow, Poland, Central Europe, Jagiellonian dynasty, inns, taverns, alehouses.

The public houses - inns, taverns, and alehouses - of Cracow during the reign of the Jagiellonian Dynasty were integral institutions for the diplomatic services of the kings, city officials, and nobility. Emissaries serving the king and other officials, even on matters of utmost importance, routinely employed public houses during their travels and work. The diplomats, wherever they traveled, used the establishments for their basic services of food, drink, and accommodation. The inns, taverns, and alehouses, however, provided the diplomats with much more, such as offering sites to learn about the latest news, gossip, and public opinion. They offered places where the

${ }^{1}$ This article is based on research conducted in Cracow, Poland, which was supported by fellowships from the U.S.-Polish Fulbright Commission, the Kosciuszko Foundation, and Western Michigan University.

Address for correspondence: dobekp@gvsu.edu 
emissaries could fraternize and they were also trusted locations for sensitive diplomatic negotiations. The locales likewise served as "post offices" where the diplomats could receive their letters.

Although scholars have scrutinized diplomacy and urban history in the Polish lands and in Cracow during the Jagiellonian period, they have only cursorily or not at all examined public houses and their role in diplomatic services. Andrzej Wyczański's "Polish Diplomatic Service in the Years 1506-1530" ("Polska służba dyplomatyczna w latach 1506-1530"), for example, extensively looks at the diplomacy of King Zygmunt I the Old (Zygmunt I Stary), but fails to mention the role of the public houses. ${ }^{2}$ While Bohdan Baranowski, considers public houses in medieval and early modern Cracow, his work functions only as a brief overview of the establishments from the Middle Ages to the twentieth century, which does not consider the locations as integral to diplomatic services. ${ }^{3}$ Other scholars likewise provide valuable information on diplomacy and urban history, but not on the role of the public houses. ${ }^{4}$

The Kingdom of Poland, during the Jagiellonian Era, moved towards functioning as a noble democratic monarchy. ${ }^{5}$ Kings dominated politics by creating domestic and foreign policy, proposing legislation, and vetoing bills; but their actions were increasingly subject to the approval of the Sejm (diet). ${ }^{6}$ The Sejm met at irregular intervals until 1493 and at various locations because the gathering required the kings' summoning. Cracow, as the preferred residence of the kings in Royal Poland, hosted twenty-nine Sejm sessions between 1493 and 1569 - the most of any location. ${ }^{7}$ Additionally, while the general Sejm was not in session, local Sejmiki (dietines) could meet to perform local and national functions, such as electing deputies to the Sejm, editing resolutions, allocating tax responsibilities, distributing funds, etc. ${ }^{8}$ Attending the Sejm and the $\mathrm{Se}$ jmiki required significant investment of both time, for participation and travel, and expenditure from the king, the city, the nobility (szlachta), and the diplomats. ${ }^{9}$

2 A. Wyczański, "Polska służba dyplomatyczna w latach 1506-1530" [Polish Diplomatic Service in the Years 1506-1530] [in:] Polska stużba dyplomatyczna XVI-XVIII wieku, ed. Z. Wójcik, Warszawa 1966.

3 B. Baranowski, Polska karczma, restauracja, kawiarnia [The Polish Inn, Restaurant, Coffee Shop], Wrocław 1979.

${ }^{4}$ Among others: J. Burszta, Wieś i karczma. Rola karczmy w życiu wsi pańszczyźnianej [The Countryside and the Tavern: The Role of the Tavern in the Life of the Feudal Countryside], Warszawa 1950; J. Jedruch, Constitutions, Elections, and Legislatures of Poland, 1493-1977: A Guide to Their History, Washington, D.C. 1982; S. Kutrze ba, "Piwo w średniowiecznym Krakowie" [Beer in Medieval Cracow], Rocznik Krakowski 1898, vol. 1; S. Kutrzeba, Finanse i handel średniowiecznego Krakowa [Finance and Trade of Medieval Krakow], Kraków 2009; F. W. Carter, "Cracow's Wine Trade (Fourteenth to Eighteenth Centuries)," The Slavonic and East European Review, October 1987, vol. 65, no. 4.

${ }^{5}$ J. Wyrozumski, Dzieje Krakowa. Kraków do schyłku wieków średnich [History of Cracow: Cracow to the End of the Middle Ages], Kraków 1992; P. W. Kno1l, The Rise of the Polish Monarchy: Piast Poland in East Central Europe, 1320-1370, Chicago-London 1972.

${ }_{6}^{6}$ D. Stone, The Polish-Lithuanian State, 1386-1795, Seattle-London 2001, p. 177.

7 J. Jedruch, Constitutions, Elections, and Legislatures, pp. 90-100.

${ }^{8}$ D. Stone, The Polish-Lithuanian State, pp. 184-185.

${ }_{9}$ Najstarsze ksiegi i rachunki miasta Krakowa od r. 1300 do 1400 [The Oldest Account Books of the City of Krakow from 1300 to 1400], eds. J. Szujski, F. Piekosiński, Kraków 1878; S. Kutrzeba, op. cit. 
The king permitted emissaries to utilize the public houses throughout Europe and provided for initial expenses. If diplomats incurred expenditures beyond the primary stipend, they would cover the costs out of their own pocket and the treasury would reimburse envoys for their services on a given assignment. For example, in 1479, King Casimir IV Jagiellon (Kazimierz IV Jagiellończyk) covered the expenses incurred in Cracow of Bohemian diplomats in the sum of twenty-three Marcs, twenty-one Grosze and four Denarius for "an inn and necessities", and four Marcs, three Fertones, and six Grosze for their wine consumption. ${ }^{10}$ The evidence shows that the employment of public houses for diplomatic purposes was common practice throughout the Jagiellonian Age for both emissaries of the Polish court and other polities, such as the Holy Roman Empire.

The terminology of the primary sources when referring to public houses is not always clear and the documents often used terms interchangeably. Within the same resource, a place may receive multiple designations and this complicates determining the exact nature of the establishment. The resources most commonly designate a tavern with the Latin taberna and the Polish karczma or tawerna, an inn or hostelry with the Latin hospitium or deversorium and the Polish zajazd or gospoda, and an alehouse with the Latin celarium and the Polish piwnica. The emissaries utilized each of these establishments, but inns and taverns most frequently.

The Polish diplomat and chronicler, Jan Długosz (1415-1480), offers firsthand insight into how the diplomats employed the public houses in Cracow during the reigns of the Jagiellonian kings Władysław III of Varna (Władysław III Warneńczyk) and Casimir IV Jagiellon. Following the completion of his studies at the parish school in Nowy Korczyn, Jan Długosz began attending the University of Cracow, but after three years, he instead chose to accept a position as a notary for the Bishop of Cracow, Zbigniew Oleśnicki (1389-1455). ${ }^{11}$ Under Oleśnicki, from 1433 to 1455, Długosz learned the inner workings of the royal and episcopal courts in Cracow and positioned himself for advancement. Długosz, following Oleśnicki's death, entered the service of King Casimir IV Jagiellon and in 1467, became the tutor of the royal children. It was during this time that he began writing his Annals or Chronicles of the Famous Kingdom of Poland (Annales seu Cronici Incliti Regni Poloniae). ${ }^{12}$ The king entrusted Długosz with numerous diplomatic missions, including escorting Władyław II (Władysław II Jagiellończyk) to Prague in order to assume the Bohemian crown in 1471.

10 One Marc was worth approximately 198 grams of silver, one Ferto was worth approximately 49.5 grams of silver, one Grosz was worth approximately 3.2 grams of silver, and one Denar was worth approximately .27 grams of silver. "Summa duntaxat in hospicio pro necessariis per Bohemos receptis facit viginti tres mrc. viginti unum gr. et IIIIor den. / Summa pro vino per eos in quartis receptor facit quatuor mrc. tres frt. et sex gr." Rachunki królewskie z lat 1471-1472 i 1476-1478 [The Royal Accounts from 1471-1472 and 1476-1478], eds. S. Gawęda, Z. Perzanowski, A. Strzelecka, Kraków 1960, p. 112.

${ }^{11}$ M. Bobrzyński, S. Smolka, Jan Dlugosz. Jego życie i stanowisko w piśmiennictwie [Jan Dlugosz, His Life and Place in Literature], Kraków 1893, p. 13.

12 The Annals of Jan Dlugosz: Annales seu cronicae incliti regni Poloniae, trans. M. Michael, Charlton, West Sussex 1997. 
Długosz's Annals or Chronicles of the Famous Kingdom of Poland offers an account of more than 500 years of Polish and European history from the perspective of a valued member of the king's court and gives insight into the political, social, cultural, religious, and academic developments of the highest levels of society, which included their utilization of public houses. The work covers events from the historical foundation of the Polish lands in 965 to 1480, the year he died in Cracow. Długosz's services to the king gave him personal diplomatic experience from which he could draw to chronicle the events of the Polish kingdom. Although Długosz does not relate his own familiarity with public houses, he does provide insight into the use of these institutions in diplomacy. For instance, in 1440, when Władysław III was negotiating for the Hungarian throne, he sent "his brother, Casimir, to go out to greet the Hungarian envoys, whom he ordered to be lodged in the best inns and to be provided lavishly with all that they may need." ${ }^{\prime 3}$ The hospitality of the king was on full display when these important emissaries visited his city. On a different occasion in 1468, King Casimir IV Jagiellon housed an envoy from George Poděbrady (Jiř́ z Poděbrad) in a hostelry in Cracow. After receiving assurances from Casimir that he would intervene on Poděbrady's behalf in his hostilities with Matthias Corvinus (Hunyadi Mátyás) and the papacy, the envoy returned to his accommodations. The envoy then "sets out for home laden with the gifts that have been sent to his hostelry." 14 The Polish kings regarded the public houses in Cracow highly enough to lodge important visitors there during negotiations and did not believe housing the emissaries in such establishments would offend them. The hospitality of the kings knew no bounds and they not only provided the diplomats with a place to lodge, but also all that they may need and gifts.

Dhugosz's account suggests that the king himself had stayed at a public house while on a diplomatic mission in 1439. King Casimir had traveled to Wrockaw to meet with Bishop John of Siena, Bishop Alphonse of Burgos, Albert, the king of Hungary, Croatia, and Bohemia, with a number of his prelates and nobles, Wincenty Kot, the archbishop of Gniezno, and others to discuss the future of the crown of Bohemia. ${ }^{15}$ Following the death of Emperor Sigismund of Luxembourg in 1437, Albert and Casimir, with their own factions, both claimed the Bohemian throne. After initially agreeing to the marriage of Casimir's son, Władysław, to Albert's daughter, Elizabeth, in exchange for Albert's renunciation of the crown, Albert changed his mind and began adding other stipulations. According to Długosz, "This so angers the Poles that, without even breaking off the discussions, they make a rather disorderly

13 "In diebus autem Septuagesime venerunt ad suam serenitatem Cracoviam solennes Regni Hungarie et Elizabeth regine nuncii, videlicet Ioannes Seginensis episcopus, Mathko de Thaloncz Slavonie et Dalmacie banus, Emericus de Marcellis magister curie, Ioannes maior de Peren et Ladislaus de Paloncz, quibus Wladislaus germanum suum Casimirum cum pluribus prelatis et baronibus suis in obvium extra civitatem transmittit et illos in hospiciis honestissimis collocari et omnibus necessariis splendide et copiose procurari disponit.” Ibid., p. 477.

14 "Alacer hoc responso Albertus Kosthka in Bohemiam, regiis pulcherrimis donis sibi in hospicium transmissis neglectis, ut virtutem et modestiam nunciorum regis Polonie Prage et Wratislavie ostensam et per ora virum celebratam emularetur, regressus est maximo pavore libertus.” Ibid., pp. 567-568.

${ }^{15}$ The identity of Bishop John of Siena is uncertain as the bishop of Siena at this time was Carlo Bartoli. Ibid., p. 476. 
departure. Albert is hurt by this behaviour and tries to restrain them. The Poles, though thinking it shameful to return to their inn once they are in the saddle, yield to the tears, rather than the pleading of the papal legate." 16 Although it is unclear as to whom "the Poles" refers to, it seems to suggest the entire Polish delegation to the Wrocław conference, which would include King Casimir. The Piast kings, as written in The Deeds of the Princes of the Poles (Gesta Principum Polonorum), employed public houses and it is not surprising that Casimir and the Jagiellonians would use the services of the locales. ${ }^{17}$ If Casimir himself regarded inns as suitable accommodations for royalty, then he would not hesitate to lodge emissaries in public houses. The subsequent kings of the Jagiellonian Dynasty also continued to employ public houses for diplomacy in the fifteenth and sixteenth centuries.

One of the most well-known and well-traveled diplomats of the sixteenth century, Ioannes Dantiscus (Jan Dantyszek) (1485-1548), provided first-hand accounts of his and his colleagues' use of public houses throughout Europe, including in London, Madrid, Barcelona, Granada, Augsburg, Cracow, and many other cities, during their diplomatic and clerical missions. Around 1500, he began attending the university in Cracow, and by 1501, he entered the services of King Jan I Olbracht and after his death, King Aleksander I Jagiellon (Aleksander Jagiellończyk). ${ }^{18}$ Dantiscus continued in the royal service under the new king, Zygmunt I the Old, and by 1507, he began to carry out diplomatic missions to Prussia. ${ }^{19}$ In 1515 , he began to complete assignments for Charles I of Spain, who, in 1516, ennobled Dantiscus for his services. Dantiscus continued to serve faithfully and successfully both foreign and Polish kings for the remainder of his life. By the time of his death, Dantiscus had served four Polish kings (Jan I Olbracht, Aleksander I Jagiellon, Zygmunt I the Old, and Zygmunt II August) and had attended the courts of Henry VIII of England, Francis I of France, Charles I of Spain, Ferdinand I, Emperor Maximilian I, and various others.

Dantiscus praised and more often, lamented his stays in public houses in the extant copies of his 6,137 correspondences..$^{20}$ Of those communications, public houses and publicans appear as subjects in 183 letters and poems. Throughout these correspondences, subjects range from financial obligations, comfort, diplomacy, tippling, and many others. The letters also provided recommendations among the correspondents

16 "Et quamvis iuxta certa capitula et condiciones perpetua pax tunc conclude debuisset, quia tamen Albertus rex persuasus aliquorum Almanorum, qui Regni Polonie fortunis invidebant, consilio, subito mutare et variare huiusmodi varietatem adeo irritati sunt, ut omnibus rebus infectis ex Wratislavia sine fine, sine ordine aliquo discederent. Quorum discessum Albertus rex moleste ferens, temptabat illos omnibus viis revocare a recess. Summe enim ut princeps catholicus desiderabat firmare pacem, nisi ingenia vafra Almanorum obstitissent. Nuncii tamen regis Polonie turpe putantes redire ad hospicia (iam eqous conscenderant) discesserunt. Legatorum tamen pape et concilii sollicitati plus lacrimis quam precibus, consenciunt descendere in Namisloviam et pro pace aut treuga agere." Ibid.

17 Gallus Anonymus, Gesta Principum Polonorum: The Deeds of the Princes of the Poles, trans. P. W. Knoll, F. Schaer, Budapest-New York 2003, pp. 276-279.

${ }^{18}$ H. de Vocht, John Dantiscus and His Netherlandish Friends: As Revealed by Their Correspondence 1522-1546, Louvain 1961, p. 6.

19 Ibid.

${ }^{20}$ Inventory of Ioannes Dantiscus' Correspondence, eds. J. Ax er, A. Skolimowska, vol. 2, part 4, Warsaw-Cracow 2011, p. 11. 
about which establishments to frequent and which to avoid. This helped the diplomats secure adequate accommodations and provisions in unfamiliar lands.

A common theme, before he became bishop of Warmia, was Dantiscus's penchant to describe his financial troubles associated with life on missions and in public houses. On his return from attending a Sejm in Cracow, Dantiscus wrote multiple letters to his friends to recount the events of the diet. He also used the opportunity to complain about his expenses during the trip, which included his tenancy in a public house in the city for three months. In a letter to Jan Chojeński, Grand Chancellor and Bishop of Płock, from March 16, 1537, Dantiscus declared: "Having recently abandoned over a thousand Florins in Cracow, I am diminished to such an extent that hardly a hide remains with meat to be eaten." ${ }^{21} \mathrm{He}$ reaffirms his poverty as a result of the Sejm on November 24 in a letter to Tiedemann Giese, bishop-elect of Chełmno, in which he claimed to have spent 1,500 Marcs of his own money. ${ }^{22}$ The three-month long diet placed serious financial strains on Dantiscus and other diplomats. The emissaries hoped that they could afford the expenses of such gatherings, otherwise, they turned to patrons and friends in the hopes that they could help alleviate some of the burden.

Dantiscus's extensive correspondence with Sigmund von Herberstein (14861566), a diplomat in the Habsburgs' service, often included information on public houses, tales of merrymaking, and pleas for financial support. Von Herberstein completed sixty-nine diplomatic missions between 1515 and 1553 for Maximilian I, Charles I, and Ferdinand I and because of his valued service, he received titles, land, and wealth. ${ }^{23}$ Von Herberstein probably met Dantiscus for the first time in 1515 at the First Congress of Vienna. ${ }^{24}$ Their friendship quickly blossomed and endured to the end of Dantiscus' life. As noted previously, Dantiscus, despite his many distinctions, regularly faced financial problems during diplomatic missions and often beseeched von Herberstein for assistance. In a letter from October 29, 1515, Dantiscus wrote to von Herberstein to ask him to obtain money from the emperor because the innkeeper is demanding payment. According to Dantiscus,

At the conclusion of my letter, the innkeeper came to me with a certain vigor wishing to have the money, so now she is my enemy, therefore, she will not stay with me. I am pressed, pushed and squeezed from almost all directions by abuse, because I do not have blessings, as long as I will have had money. May you go on, as you begin to spend time with the emperor, so that I may have at least something, if not all things, by which I may be freed, so that the innkeeper remains silent for a short time. You understand, I imagine, how troublesome it is always to be pushed, beaten, strangled, etc. by creditors. ${ }^{25}$

21 "Ego quidem relictis Cracoviae nuper supra mille florenis adeo sum extenuates, quod vix pellis, carnibus consumptis, restat." Ioannis Dantisci Epistulae Latinae, eds. J. Axer, A. Skolimowska, vol. 1, part 1, Warsaw-Cracow 2004, p. 160.

22 "Si non fuisset profectio anni praeteriti ad comicia Regni Cracouiam, in quibus mille quingentas marcas de meis hic censibus ex pecuniis propriis absumpsi." Ibid., p. 357.

${ }^{23}$ Ioannes Dantiscus' Correspondence with Sigmund von Herberstein, eds. J. Ax er, A. Skolimowska, vol. 1, part 2, Warsaw-Cracow 2008, p. 14.

${ }^{24}$ Ibid.

25 "In conclusione litterarum venit ad me hospes cum quadam vehementia volens habere pecuniam, quae nunc mihi hostis est, ideo mecum non habitat. Urgeor, impulsor et angor fere ab omni parte, propter 
In desperation, Dantiscus pawned his envoy's chain and his rings and continued to beseech von Herberstein as a minister-member of the Hofkriegsrat to find relief for Dantiscus' troublesome position. ${ }^{26}$

Dantiscus' letters also reveal that he was not the only Polish diplomat during the sixteenth century to employ public houses during his missions. In a letter to von Herberstein from February 23, 1540, for instance, Dantiscus apologized to von Herberstein for not responding to a message because their mutual friend, Mikołaj Nipszyc, who was supposed to deliver the correspondence, needed to leave his inn suddenly. ${ }^{27}$ Nipszyc served King Zygmunt I at the court in Cracow from 1506 until his death in 1541, during which time he carried out missions from the Polish king to the Grand Master of the Teutonic Order, Albrecht von Hohenzollern, to Ferdinand I, to the Assemblies of Royal Prussia, and to various others. ${ }^{28}$ Despite Nipszyc's prominent position at the Polish court, he still needed to secure his own accommodations while on diplomatic missions as did other emissaries.

The use of public houses by diplomats was not exclusive to the Polish court. Dantiscus' extensive correspondence with emissaries in the service of other polities shows that this was common practice throughout Europe during the Jagiellonian period. For example, three of Dantiscus' most frequent correspondents, Cornelius de Schepper, secretary and councilor to Emperor Charles V, Alfonso de Valdés, secretary of Emperor Charles V, and the aforementioned Sigmund von Herberstein discuss their experiences in public houses. In his correspondence to Dantiscus from Maastricht on January 1, 1531, de Schepper recommends a public house for Dantiscus: "The innkeeper of the house is a good man and assuming from the drinking, the hostess is not boorish. I believe it will not be a bad inn for you." ${ }^{29}$ While in a letter dated September 12, 1527 from Palencia, de Valdés informs Dantiscus: "I have found a sufficiently comfortable inn, which you, if it happens that you are to come here, can use." 30 The diplomats wanted to provide recommendations for their fellow emissaries to ensure that they could find adequate accommodations. Not only was comfort an important

maledictas, quia non habeo, benedictas, dum habuero, pecunias. Generositas Vestra pergat, ut incepit, agree cum caesarea maiestate, ut saltem aliquid habeam, si non omnia, quo sim solvendo, ut hospes paulisper conquiescat. Scit, ut opinor, Generositas Vestra, quam molestum est a creditoribus semper urgeri, impulsari, angi etc.” Ibid., p. 73.

${ }^{26}$ Ibid., p. 21. "In Londino vero ab hospite absolve non poterat, nisi vendita catena aurea, quae trecentos ducatos continebat", "Letter \#6225" [in:] Corpus of Ioannes Dantiscus' Texts \& Correspondence, eds. A. Skolimowska, M. Turska, K. Jasińska-Zdun, http://dantiscus.al.uw.edu.pl/?f=letterS ummary\&letter $=6225$.

27 "Quod cum communi amico domino Nibschicz non rescripserim, illius culpa accidit, qui a me insalutato hospite abiit." Ioannes Dantiscus' Correspondence with Sigmund von Herberstein, p. 153.

${ }^{28}$ Ibid., p. 84n1.

29 "Hospes huius domus vir est bonus et praesumens de potu, hospita non infaceta. Credo non habiturum te malum diversorium." "Letter \#579" [in:] Corpus, http://dantiscus.al.uw.edu.pl/?f=letter Summary\&letter $=579$.

30 "Nactus sum hospitium satis commodum et quod tibi, si quando huc venire contigerit, usui esse poterit." "Letter \#5745" [in:] Corpus, http://dantiscus.al.uw.edu.pl/?f=letterSummary\&letter=5745. 
factor in determining a public house, but so was the quality of the publican and the drinking.

Dantiscus also sought to ensure that other Polish envoys received proper accommodations, including occupancy in public houses. For instance, in a letter from March 19, 1543, Stanisław Hozjusz, royal secretary to Zygmunt I the Old, described leaving an inn, which Dantiscus had arranged for him in Cracow. ${ }^{31}$ In a letter from 1537 to his friend Tiedemann Giese, Dantiscus informed Giese that Mikołaj Nipszyc and royal chamberlain Marcin Wolski would be traveling to Frombork in order to attend the election of the bishop of Warmia. ${ }^{32}$ Dantiscus was particularly interested in the election because he wished to secure the bishopric for himself and therefore, it was in his best interest to ensure the proper treatment of its participants. Dantiscus asked Giese "to receive the eight-horse retinue at his house." 33 If he is unable, Dantiscus asked him, "However, may you meet with the venerable chapter to make it possible for the royal orator, who was next sent to our monastery, to have a comfortable inn. ${ }^{34}$ Dantiscus wanted to ensure that Giese provided proper and comfortable accommodations for a man of Nipszyc's position. Dantiscus added in the postscript: "My messenger will inform you on the customs of lord Nipszyc, which, to the extent that they please me, I hope, they will please you." ${ }^{35}$ The customs to which Dantiscus was referring was Nipszyc's love of drink, cards, and dice and it is likely that Giese spent the night drinking and playing games with Nipszyc. ${ }^{36}$

Public houses were not simply places for diplomats to reside in, but they were also locations where important negotiations took place. This is evident from a letter dated January 22, 1537 in Cracow from Dantiscus to the bishop of Warmia, Maurycy Ferber. The correspondence reveals information on Dantiscus' residency at a public house while attending the Sejm in Cracow. After attending a meeting of the Royal Council, in which King Zygmunt I the Old received the demands of the Prussian representatives - "The Prussian gentry's envoys demanded from the king that he consult them when appointing lay and church officials in Prussia" - the king gave Dantiscus the authority to negotiate with the emissaries at his inn on the next day. ${ }^{37}$ According to Dantiscus, "After the reading of the demands, the king ordered that the messengers meet with me on the next day in my inn, if by chance, we reach an agreement on the

31 “Letter \#2638" [in:] Corpus, http://dantiscus.al.uw.edu.p1/?f=letterSummary\&letter=2638.

${ }^{32}$ Ioannis Dantisci Epistulae Latinae, vol. 1, part 1, pp. 224-225.

${ }^{33}$ Ibid.

34 "In praesens non attingo aliud, quam, quod, si Dominacio Vestra illum commode cum equis octo in domum suam accipere potest, ob eas causas, quas descripsi in nouissimis, rem mihi gratam nobisque non invtilem vtrisque faciet; sin vero, Dominacio Vestra cum venerabili agat capitulo, vt orator regius, qui etiam ad conuentum nostrum proximum est missus, commodum hospicium habere possit, de quo per istum meum nuncium cercior inter eundeum fieri possit." Ibid., p. 225.

35 "De moribus domini Nibschicz iste meus nuncius Dominacionem Vestram edocebit, qui, quemadmodum mihi placent, it et ut Dominacioni Vestrae placeant, oro." Ibid.

${ }^{36}$ Ioannes Dantiscus' Correspondence with Sigmund von Herberstein, vol. 1, part 2, 84n1; T. Borawska, Życie umysłowe na Warmii w czasach Mikołaja Kopernika [Intellectual Life in Warmia during the Times of Nicolaus Copernicus], Torun 1996, pp. 111-112.

${ }^{37}$ Ioannis Dantisci Epistulae Latinae, vol. 1, part 1, p. 133. 
matter." ${ }^{38}$ The king, rather than providing accommodations for his lead negotiator on issues regarding Polish policies in Prussia, regarded the public house as a place adequate for lodging and as a place sufficient for vital negotiations. The king believed that the public house in which Dantiscus was residing was a sufficient location for political negotiations with the Prussian envoys, despite the possibility of other patrons, the publicans, or even spies hearing such sensitive information.

The public houses of Cracow likewise functioned as a place for the diplomats to receive their correspondence. The emissaries were frequently traveling from place to place without a permanent address. For destinations closer to the Polish lands, such as Hungary or the Czech lands, the king dispatched royal messengers regularly. The king, for instance, sent six envoys to Hungary in 1518, five in 1523, and six in 1524 at a cost of about ten Florins each. ${ }^{39}$ Sending messengers to more distant locations was costlier and more complicated, and the king resorted to this in matters of utmost importance. More commonly, the ruler relied on merchants and other travelers who journeyed recurrently to various destinations, thus establishing regular correspondence routes. For example, merchants brought monthly messages from Spain, via Naples, to Rome, and afterwards, to Poland; the same was true for the route from Spain, via Antwerp, to Augsburg or Wrocław, and lastly, to Cracow. ${ }^{40}$ According to Andrzej Wyczański, in the sixteenth century, communications between Rome and Poland took around eight to ten weeks, northern Germany and Poland three to four weeks, the Netherlands and Poland six to eight weeks, Spain to Poland three to five months, Austria to Poland three to six weeks, the Czech lands to Poland two to four weeks, and Hungary to Poland two to four weeks. ${ }^{41}$ The diplomats usually then received the letters from the merchants or travelers or from publicans at the public house.

The correspondence of Dantiscus provides a glimpse into the use of public houses as a place for receiving missives. Throughout various letters, he makes a brief mention of receiving letters from different individuals at the public house, in which he was currently residing. For example, in a letter from May 5, 1525 to King Zygmunt I the Old, Dantiscus describes receiving and reading communiqués from the king written March 13 at his inn in Toledo. ${ }^{42}$ Likewise, in Palencia, on September 10, 1527, he received correspondence at his public house from Balthasar Merklin von Waldkirch, vice-chancellor of the Holy Roman Empire..$^{43}$ In a letter written on March 23, 1545, Marco de la Torre, Provincial of the Franciscan Order in Poland, informed Dantiscus that he did not remember the contents of the missive he received at the

38 "Post lectionem libelli iniunxit serenissima maiestas regia ipsis nunciis, ut nobiscum postero die in meo hospicio convenirent, si forte ad aliquam inter nos composicionem res duci posset." Ibid., p. 135.

${ }^{39}$ A. Wyczański, "Polska służba dyplomatyczna w latach 1506-1530”, p. 26.

${ }^{40}$ Ibid., p. 27.

${ }^{41}$ Ibid., p. 32.

42 "Discessique ad laetius prandium cum litteris Maiestatis Vestrae Serenissimae in deversorium meum." "Letter \#244 [in:] Corpus, http://dantiscus.al.uw.edu.p1/?f=letterSummary\&letter=244.

43 "Hesterno sero intravi civitatem Palentianam et extra portam obviam mihi occurrit cursor et senor Mutza de Spola, Dominationis Vestrae qui mihi et Valdesio una praesentavit litteras, quas, cum ad hospitium veni, aperui." "Letter\#374" [in:] Corpus, http://dantiscus.al.uw.edu.pl/?f=letterSummary\&letter=374. 
public house in Cracow. ${ }^{44}$ The public houses provided these itinerant individuals with a semi-permanent location, where they could receive important correspondence and continue to communicate with their places of origin.

The public houses in Cracow and throughout Europe were essential to the functions of emissaries and the inner workings of diplomacy. The establishments gave the itinerant envoys a semi-permanent location from which they could carry out their missions. This included acting as places for obtaining the basic services of food, drink, and accommodation, learning about the latest news, gossip, and public opinion, negotiating vital agreements, and receiving correspondence. Employing the public houses for these diplomatic missions, however, was costly and the diplomats often struggled to pay for the expenses upfront. The Polish kings periodically used public houses themselves and permitted the envoys to employ the public houses wherever they traveled and would hopefully reimburse them upon their return. The kings occasionally displayed their hospitality by paying for the costs of lodging, food, drink, and even by bestowing gifts on the representatives. The network of public houses throughout Cracow, the Polish lands, and Europe allowed the kings and officials to maintain extensive diplomatic relations and to oversee their expansive territory.

\section{BIBLIOGRAPHY}

The Annals of Jan Dlugosz: Annales seu cronicae incliti regni Poloniae, ed. and trans. M. Michael, Chichester 1997.

Baranowski, B., Polska karczma, restauracja, kawiarnia, Wrocław 1979.

Bobrzyński, M., Smolka, S., Jan Dlugosz, jego życie i stanowisko w piśmiennictwie, Kraków 1893.

Boraw ska, T., Życie umysłowe na Warmii w czasach Mikołaja Kopernika, Toruń 1996.

Burszta, J., Wieś i karczma. Rola karczmy w życiu wsi pańszczyźnianej, Warszawa 1950.

Carter, F. W., "Cracow's Wine Trade (Fourteenth to Eighteenth Centuries)," The Slavonic and East European Review, October 1987, vol. 65, no. 4, pp. 537-578.

Gallus Anonymus, Gesta Principum Polonorum: The Deeds of the Princes of the Poles, trans. P. W. Knoll, F. Schaer, Budapest-New York 2003.

Inventory of Ioannes Dantiscus' Correspondence, eds. J. Axer, A. Skolimowska, vol. 2, part 4, Warsaw-Cracow 2011.

Ioannes Dantiscus' Correspondence with Sigmund von Herberstein, eds. J. Axer, A. Skolimowska, vol. 1, part 2, Warsaw-Cracow 2008.

Ioannis Dantisci Epistulae Latinae, eds. J. Axer, A. Skolimowska, vol. 1, part 1, WarsawCracow 2004.

Jędruch, J., Constitutions, Elections, and Legislatures of Poland, 1493-1977: A Guide to Their History, Washington, D.C. 1982.

44 "De hospitio nihil memini in litteris, quia non erat opus repetere, quod toties Paternitati Vestrae Reverendissimae viva voce fuerat inculcatum." "Letter \#2807” [in:] Corpus, http://dantiscus.al.uw.edu. $\mathrm{pl} /$ ?f=letterSummary\&letter $=2807$. 
Knoll, P. W., The Rise of the Polish Monarchy: Piast Poland in East Central Europe, 1320 1370, Chicago-London 1972.

Kutrzeba, S., Finanse i handel średniowiecznego Krakowa, Kraków 2009.

Kutrzeba, S., "Piwo w średniowiecznym Krakowie," Rocznik Krakowski 1898, vol. 1, pp. 53-58.

Laboratory for Source Editing and Digital Humanities, Corpus of Ioannes Dantiscus' Texts \& Correspondence, A. Skolimowska, M. Turska, K. Jasińska-Zdun, http://dantiscus.al.uw.edu.pl/?menu=call\&f=search.

Najstarsze księgi i rachunki miasta Krakowa od r. 1300 do 1400, eds. J. Szuj ski, F. Piekosiński, Kraków 1878.

Rachunki królewskie z lat 1471-1472 i 1476-1478, eds. S. Gawęda, Z. Perzanowski, A. Strzelecka, Kraków 1960.

Stone, D., The Polish-Lithuanian State, 1386-1795, Seattle-London 2001.

Vocht, H. de, John Dantiscus and His Netherlandish Friends: As Revealed by Their Correspondence 1522-1546, Louvain 1961.

Wyczański, A., "Polska służba dyplomatyczna w latach 1506-1530" [in:] Polska stużba dyplomatyczna XVI-XVIII wieku, ed. Z. Wójcik, Warszawa 1966.

Wyrozumski, J., Dzieje Krakowa. Kraków do schyłku wieków średnich, Kraków 1992. 
